This is a self-archived version of an original article. This version may differ from the original in pagination and typographic details.

Author(s): Häkkinen, Ville

Title: Redescribing the Nation : Anti-Semitism as a tool of nation-building in the Hungarian Numerus Clausus debates, 1920-1928

Year: 2018

Version: Accepted version (Final draft)

Copyright: (C) John Benjamins

Rights: In Copyright

Rights url: http://rightsstatements.org/page/InC/1.0/?language=en

Please cite the original version:

Häkkinen, V. (2018). Redescribing the Nation : Anti-Semitism as a tool of nation-building in the Hungarian Numerus Clausus debates, 1920-1928. Journal of Language and Politics, 17(5), 655675. https://doi.org/10.1075/jlp.18011.hak 


\title{
Redescribing the Nation
}

Anti-Semitism as a Tool of Nation-building in the Hungarian Numerus Clausus Debates, $1920-1928$

\author{
Ville Häkkinen \\ University of Jyväskylä
}

Boosting national spirit through projection of otherness is not a new phenomenon, at least in authoritarian regimes. Yet the role of anti-Semitism in the Numerus Clausus debates in the Hungarian parliament in 1920 and 1928 is worth deeper analysis, as it bore a peculiar role in the Hungarian interwar counterrevolutionary nation-building. The Numerus Clausus law of 1920 set ethnic quotas to university enrolment; the explicit argument for this was countering the Jewish 'over-representation' in Hungarian society. However, in 1928 the law was amended, abolishing (in principle) the said quotas; this time the arguments favoured national consolidation, where segregation was to be moderated. In both cases, the national elites construed and made use of nation-centred political rhetoric, but used it for differing ends in different times. This article shall analyse the debates of the Hungarian Parliament concerning the Numerus Clausus laws, especially from the viewpoints of nation-building and rhetoric of exclusion.

Keywords: 1920s, anti-Semitism, Hungary, nation-building, political culture, political rhetoric

\section{Introduction}

Boosting national spirit through projection of enemy figures is by no means a unique phenomenon, at least in authoritarian regimes. Yet the anti-Semitism present in the Numerus Clausus debates in the Hungarian parliament in 1920 and 1928 is worth deeper analysis, as it bore a peculiar role, both symbolically and practically, in the Hungarian nation-building in the interwar counterrevolutionary political culture. ${ }^{1}$

After the democratic and communist revolutions of 1918-19, the Hungarian conservativerightist counterrevolution prevailed. The counterrevolutionary nation-building occurred in the state of internal and external insecurity following Hungary's defeat in the First World War (Romsics 1999, 89-91, 98-99, 108-112). When returning to power the pre-war elite had to legitimize its power structure, consolidate its position vis-à-vis the Entente, bring Hungary through the peace treaty of Trianon and accommodate the domestic extreme Right, towards which it was in a debt for carrying out the counterrevolutionary terror (Bodo 2010, 723). As a result of these conflicting motives, the interwar political culture was never a coherent system, but involved several overlapping discourses, which were contested and redefined throughout the era.

The diverse forms of anti-Semitism, both in political discourse and in concrete legislation, were among the tools of the exclusive nation-building. It was most prominently operationalized in the Numerus Clausus -legislation as well as the Jewish laws of 1938-41. The Numerus Clausus of 1920 set ethnic quotas to university enrolment; the explicitly voiced

\footnotetext{
${ }^{1}$ This article concentrates on the use of language in the debates concerning the legislation. On more detailed analysis about the Numerus Clausus and anti-Semitism in interwar Hungary see e.g. Karady and Nagy 2012; Ungváry 2013.
} 
argument for this was countering the Jewish 'over-representation' in Hungarian society. However, in 1928 the law was amended, abolishing (in principle) the said quotas; this time the arguments favoured national consolidation, where radical segregation was moderated, at least rhetorically. In both cases, the elite construed and made use of nation-centered political rhetoric, but used it for differing ends in different times. The arguments for and against the limitations of Jewish influence in the Hungarian society reveal the construction and reformulations of the Christian National political thought as an umbrella concept, but also the polyphonic nature of the Hungarian parliament, which the government made use of: as the extreme Right demanded always stricter discrimination and the liberal Left its complete abolition, the government could always legitimize its resolutions as 'golden mean against the two extremes'.

This article analyses the debates of the Hungarian Parliament concerning the Numerus Clausus laws, especially from the viewpoints of nation-building, parliamentary procedure, rhetoric of exclusion and transnational discourses.

\section{Sources and methodology}

Methodologically, the article is based on analysis of parliamentary debates, especially individual speech acts and rhetorical construction of arguments. ${ }^{2}$ Concentrating on the micro-level of debate, special emphasis is placed on construction of arguments as acts of connection (or deliberate disconnection): when the matter under discussion is connected to a shared experience or value, it is also revaluated, either in endorsement or contempt. A version of rhetorical redescription or paradiastole (Skinner 1999), connecting argument can have diverse effects and range from a subtle reference to a broad narrative. These include direct conceptualizations, such as rhetorical construction of Jews as non-Hungarian, as well as historical arguments based on canonized Hungarian history culture or recent experiences, such as the revolutions. In creating such arguments, speakers attempt to connect their agenda to the (assumed) expectations of the audience. These connections are rhetorical acts that can take the form of comparison, identification, confrontation or redescription. All of these create links between real word processes (actions, historical events) and abstractions (values, ideals). When these connecting acts are studied in their original context, they can reveal which ways of rhetorical persuasion were valid, that is: what were the expectations politicians wanted to fulfil and what kind of policies they pursued on that basis. Use of language presents a key to political cultures and mentalities, for in order to a speech act to be credible it has to remain within the confines of the accepted ideological and mental background. Parliamentarians went to great lengths to reinforce their arguments by connecting them to widely accepted notions (see also Kaarkoski 2016, 30-32).

The article also touches the conceptualization of the people within the political culture: the Hungarians were not conceptualized as politically active members of a demos, but an organic, all-embracing nation, the qualifications of which were being defined top-down, with little interest in its political activation. Historio-political arguments, such as the numerous references to the revolutions of 1918 and 1919, were used to exclude certain opponents from the nation and move them to the suspicious sphere of revolutionaries.

\footnotetext{
${ }^{2}$ On the tradition of studying parliamentary history from this viewpoint, see Ihalainen 2016; Häkkinen 2014; Kaarkoski 2016.
} 
The Hungarian parliamentary debates are chosen as the focus of the analysis, despite the fact that Hungary was in practice a semi-authoritarian system, where parliamentary democracy was limited by several decrees, including open ballot and limitations in suffrage (Romsics 1999, 183). With regards to the theoretical framework of parliamentary language (see Editorial), the article considers an interesting case, where the limits of the parliamentary language and parliamentary culture were largely under constant renegotiation: the government wanted to make use of the parliament as a tool of legitimization of its policies, whereas the Liberal and Social Democratic opposition actively challenged the legitimacy of the counterrevolutionary power structure. In such a confrontational polity, the extent of deliberation was actively limited by un-parliamentary and extra-parliamentary obstruction, as well as the House rules that favoured the government. Still, parliament remained the arena for open debate, free from constraints of censorship and other limitations of free speech, which were in force in Hungary (Püski $2006,259)$.

Within the debates, one can analyse what kind of arguments were rhetorically valid; which were broadly accepted and which could be contested; what kind of concepts and experiences remained unquestioned - the most valuable objects of rhetorical connection. In this case, the analysis reveals how a certain discriminatory practice, namely antiSemitism, was applied and contested in the parliamentary debate, including negative stereotypization, denial of societal integration and pseudo-rationalizing arguments of 'relative equality'. The changes of wording, changes in the convincing power of certain arguments, can reveal shifts in the power structures and formations. Thus, even as parliamentary arguments seldom posed severe challenge to the governmental policies, they reveal the basis of the political culture embedded in language (See also Ilie 2016, 134).

\section{Numerus Clausus of 1920 - anti-Semitism within the counterrevolutionary discourse}

The Numerus Clausus law, officially "Law concerning the rules of enrolment in the establishments of higher education" (Törvény a felsőoktatási intézményekbe való beiratkozás szabályairól, Law XXV/ 1920) ${ }^{3}$ was debated in the Hungarian National Assembly between September 2 and 22, 1920. As its name tells, the law set up mandates to limit the number of students accepted in universities in order to control overcrowding, mostly caused by loss of territory in the Trianon peace treaty and closing of the universities in cities ceded to neighbouring countries (Hanebrink 2006, 82).

However, the law also set up quotas for "particular races and nationalities" (egyes népfajok és nemzetiségek, Law XXV/ 1920, §3) in universities: the share of a nationality group among the university students should not exceed the proportion of the said group in the whole population (Law XXV/ 1920, §3).4 Also present were vaguely worded qualifications of "loyalty towards nation" and "trustworthiness" (nemzethüség, megbízhatóság, Law XXV/ 1920, §1). No single wording explicitly mentioned Jews, but in the parliamentary debate, anti-Semitism was open and apparent.

\footnotetext{
${ }^{3}$ The complete references to the original sources are found in the Appendix. This and all translations hereafter are my own.

${ }^{4}$ Even as the quotas were set for "all races and nationalities", Jews were the only ethnic group affected, as other minorities rarely applied for higher education in considerable numbers. (Kovács 2012, 28.)
} 
Ferenc Usetty, the secretary of the Committee for Education, who presented the bill, began his argument in counterrevolutionary tone by reminding the House of the past revolutions and the unbearable treaty of Trianon, after which the Hungarian nation was in desperate need for reforms in order to survive. Especially, it could no longer support unemployed degree-holders, a group that was dubbed "the intellectual proletariat" (szellemi proletariátus, Usetty 1920) - thus connecting it with the negative memory of the revolutions. Later speakers further reinforced this connection, directly accusing the said group of igniting the revolutions - and pointing out that suspiciously many of its members were Jews (see e.g. Bernólak 1920; Schandl 1920).

Usetty continued with the rationalizing argument that no university could maintain high academic standards with the present overcrowding of students, thus the limitations were a necessity (Cf. Kovács 2012, 34). Also here the Jewish question was brought in: Usetty presented statistics that showed Jews causing this overcrowding in growing numbers - thus introducing the argument of over-representation: how could Jews form the majority of university students, as they were only a minority in population (Usetty 1920)? ${ }^{5} \mathrm{He}$ concluded his speech by emphasizing the need of original, pure and Christian Hungarian identity:

(1) "... only such persons may be the [future] leaders of the Hungarian Nation, whose traditional Hungarian identity and Christian worldview remain unquestioned."

(... csak oly emberek lehetnek majd a magyar nemzet vezetői, akiknek tradicionális magyarságához és keresztény világfelfogásához kétség nem fér. Usetty 1920)

István Haller, the minister of education and church affairs, then continued with a call for intellectuals, who would embrace the Hungarian tradition, not duplicate foreign models. Thus, the education system was to be revised to foster a new kind of patriotic intellectuals who would approve their obligation towards the nation (Haller 1920a). Haller attacked the concept of liberalism, arguing that the liberal politics of the past decades had brought Hungary to collapse; he reminded the House of the great liberal statesmen as Ferenc Deák and József Eötvös, but also argued that even those men had always been more Hungarian patriots than liberals.

(2) "... if they had foreseen that the liberalism they had initiated was later distorted, twisted from its real form, deformed and expropriated, and that it would lead the Hungarian Nation to the depths of national despair ... they would not have chosen that way."

(... ha ók elöre látták volna, hogy az a liberalizmus, amelyet ók kezdeményeztek, amelyet késóbb elferdítettek, valódiságából kiforgattak, eltorzítottak és hívatlanul kisajátítottak, a magyar nemzetet a nemzetietlenségnek milyen stációjához fogja vezetni ...nem indultak volna meg ezen az utón. Haller 1920a, 159; see also Schandl 1920)

Haller rhetorically disconnected the historical liberal statesmen from the ideology of liberalism, which had since their days turned dangerous to the nation. This was a preemptive argument against any defence of liberalism based on those canonized historical

\footnotetext{
${ }^{5}$ Various statistics of over-representation, tailored to meet the political ends, were brought up repeatedly during the debate (see e.g. Bernólak 1920, 184-185; Schandl 1920, 337-338).
} 
figures. Therefore, Hungarians should not be afraid of accusations of being reactionary; such accusations were mere tools of the foreign powers that already had weakened Hungary with the ideology of liberalism and did not want to see it gaining strength through a national spirit (Haller 1920a; Szücz 1920). A strong redescription of the concept of liberalism legitimized treating liberty as conditional: people should be granted liberties only to the extent that they do not turn harmful to the nation. Similar redescription was performed on the concept of academic freedom; it must not mean liberty of radical agitation in universities, but liberty to conduct objective and valuable studies and to participate the national reconstruction (Herrmann 1920; Szabó 1920) ${ }^{6}$

Even those members who argued in favour of moderate liberalism, agreed with such redescriptions and made concessions to anti-Semitic mentality, accepting in principle the argument of over-representation, but calling for more thorough reforms in education than just punishing the Jewry (Ugron 1920a; Rupert 1920). Another argument against the law was socio-political; the limitations in university enrolment would eventually turn against the children of poorer Christian families, not the wealthy Jews, who could always send their children to foreign universities. This argument was clever play on political contingency: it implied that the law had an unwritten, expected outcome of discrimination against the Jews, but that it also had an unwritten and unexpected consequence that would befall the povertystricken Hungarians (Rupert 1920). Even these moderate arguments were met with unparliamentary and extra-parliamentary harassment, showing the harsh counterrevolutionary mentality prevalent in the House. Speeches in favour of equality were constantly heckled and interrupted (see e.g. Vasadi-Balogh 1920; Ugron 1920a). Liberal MP Gábor Ugron even complained that his house had been vandalized the day following his speech (Ugron 1920b). This was received with sarcastic remarks by other MPs - showing that the dominant mentality had little sympathy for the liberal opposition.

The concepts of race and assimilation ${ }^{7}$ were pivotal in the debates. Firstly, the assimilation of Jews in Hungarian society during the past centuries was rendered as either totally failed or at least imperfect (Schandl 1920; Prohászka 1920). The concepts of race, nationality and religion were considerately obscured to rhetorically construct the irrevocable otherness of Jews; a Jew whose family had lived in Hungary for centuries, or a Jew who had converted to Christianity still possessed the negative non-Hungarian 'racial' traits (Szúcz 1920). To support this, minister Haller quoted several Jewish authors, who had argued against assimilation and in favour of Zionism, to demonstrate that even if some individual Jews wanted to live as Hungarians, the great mass of them was congenitally against it (Haller 1920). As MP Vidor Dinich put it straight: "There is no such thing as a Hungarian Jew!" (Olyan nics: magyar zsidó! Dinich 1920a)

The races were represented against each other, but not necessarily hierarchically. Jews were even described to possess positive racial features such as solidarity and mutual assistance towards their kin, high literacy and respect of education. However, these were turned against them, because they created an unfair advantage when compared to Hungarians. This had resulted in capital flowing from traditional, aristocratic Hungarian families to commerce-oriented Jews in the past decades (Milotay 1920). Moreover, their leading role in commerce and economy was presented as abuse of Christian Hungarians,

\footnotetext{
${ }^{6}$ In the contemporary discourse, other civil rights were described as conditional quite similarly (see e.g. Bethlen 1921).

${ }^{7}$ One might also use the term integration, which in fact was well-developed in Hungary, but the contemporary discourse not only preferred the concept of assimilation but also actively denied it (see Ungváry 2013, 14).
} 
who actually conducted the menial work, as Jews only gathered the profits (Herrmann 1920; Dinich 1920b; Haller 1920b). The popular, stereotypic image of a plutocratic Jew, linked to secretive and unpatriotic organizations as the Free Masons, gathering wealth and influence through unfair means, was thus applied also in the Hungarian discourse (Milotay 1920; Haller 1920b).

That being said, the Jewish over-representation was simultaneously represented as a weakness of the Hungarian race, which had left the leading role to slip from its hands. In rhetoric, the law was a just measure to defend the ailing Hungarian race and return it to its former glory (Bernólak 1920; Schandl 1920; Prohászka 1920; Gömbös 1920). In such mentality the quotas were easily introduced, but rhetorically mitigated on the basis of equality as proportional: the quotas were presented as technically neutral, so seemingly there was to be neither inordinate discrimination nor favouring of Jews (Bernólak 1920).

Race, nation and society were all strongly organic concepts that could have illnesses or wounds and that had to be treated. This led to a question whether laws like Numerus Clausus were actually treating the actual illness or merely its symptoms. Many accepted that social problems were of deeper nature, but also accepted that for the time being, Numerus Clausus would do for a temporal medicine (Giesswein 1920; Haller 1920b).

Another argument used against Jews was connecting them to the context of First World War. Especially those MPs who had served in the army, pictured Jews as cowardly and unpatriotic, lurking in the home front and gathering fortunes on the expense of the suffering Hungary (Bernólak 1920; Dinich 1920b). This, coupled with the picture of Jews as revolutionaries, was a formulation similar to the German Dolchstosslegende (Romsics 2001, 22). It was also a complete reverse of the 'no conscription without representation' -kind of arguments used in suffrage debates in Western European legislatures; as it was (ostensibly) proved $^{8}$ that Jews had not fulfilled their duty in the front, it was legitimate to limit their rights in favour of inherently patriotic Hungarians.

Christianity was applied in Hungarian political discourse as a concept uniting the nation and excluding its others, especially Jews. Therefore, it has been argued that the counterrevolutionary anti-Semitism was actually based on the tradition of religious persecution (Cf. Hanebrink 2006, 90-93, 105-107). However, in practice Christianity meant little more than a universal epithet to nationalism. ${ }^{9}$ Even bishop Ottokar Prohászka, a wellknown orator of the radical Right and avid supporter of the legislation, did not base his endorsement of Numerus Clausus on religious motives, but contemporary politics; not on Jews' historical or theological otherness but on their negative influence in the contemporary Hungarian society (Prohászka 1920).

The discourse on Numerus Clausus was clearly a child of the post-war, counterrevolutionary mentality. It embodied the fears projected by both the loss of Greater Hungary and the tumultuous revolutions. The loathing towards revolutionaries in general was operationalized in the concepts of 'intellectual proletariat' and 'revolutionary liberals', the embodiment of both being a Jew. Against them, it was obviously acceptable to use tools of 'legitimate self-defence' of the Hungarian nation.

\footnotetext{
${ }^{8}$ Several statistics were again used (see e.g. Prohászka 1920, 350; Gömbös 1920, 374; Haller 1920b, 469).

${ }^{9}$ With few exceptions (cf. Szúcz 1920, 378; Kovács 1920, 453).
} 
The few liberal-minded MPs were shoved away by repeated interruptions (see Pető 1920; Sándor 1920; Bródy 1920), as most of the House was occupied by counterrevolutionary, conservative or radical Right (Hubai 2001, 21-24). The tumultuous debate on Numerus Clausus was also an example of the relatively new parliamentary culture, ${ }^{10}$ which had not yet established its conventions. Interruptions were common, MPs were allowed to speak off the subject (see e.g. Szádeczky 1920), and in some instances, even the Speaker of Parliament was not completely aware of the procedure (See e.g. Bottlik 1920).

As an indication of the counterrevolutionary transition, ideological differences between the groups on the political Right were already emerging. The governmental side relied more on rationalist and quasi-tolerant arguments, emphasizing their 'objective' stance on the matter; that the law did not pursue anti-Semitism but on the contrary, offered all races and nationalities an 'equal' share (Bernólak 1920; Schándl 1920). Even after uttering bitter comments about the Jews' role in the revolutions, MPs could return to argue that the legislation only performed justice and actually prevented violent anti-Semitism in the society (see e.g. Herrmann 1920; Ereky 1920).11 More radical MPs, organizing under the idea of race defence (fájvédelem), went so far to oppose the Numerus Clausus bill, as for them it was too weak a measure (Dinich 1920). Their leader, Gyula Gömbös, the future radical Prime Minister of Hungary, despite personally accepting the bill, demanded measures to defend the purity and strength of the ancient Hungarian race, which the nation had lost due to unhealthy Western and Jewish influence (Gömbös 1920). There he paved the way for ideology that was to define the domestic radical Right for the following 15 years: concentrating on the Hungarian race and Hungarian national spirit, struggling against internal and external enemies - Jews and Communists as well as royalists and aristocracy; eastern influence as well as western.

\section{From counterrevolution to consolidation - a way to the amendment in 1928}

In the early 1920s, international goodwill towards Hungary had been scarce since the White terror and by no means reduced by the Numerus Clausus legislation. At the same time, numerus clausus was being used reciprocally in Romania, where Hungarians had been placed under similar restrictions to university enrolment. The Romanian Hungarians had already in 1922 appealed to the Hungarian Parliament to repeal the legislation (Kovács $2012,31)$.

By the year 1928, political situation and discourse had changed remarkably. István Bethlen, Prime Minister since 1921, had gathered the majority of the former Christian National and Smallholder Party members under a single government party, The Unity Party. Bethlen, himself a moderate conservative, was building a policy of consolidation, actively distancing his line from the counterrevolutionary radicals (see e.g. Sakmyster 1994, 22-23).12 In addition, the recent developments in foreign policy, especially Hungary's entry into the League of Nations, the Treaty of friendship with Italy and, to a lesser extent, Lord Rothermere's Justice for Hungary -campaign in Britain, had created confidence within the

\footnotetext{
${ }^{10}$ The first post-revolutionary Hungarian Parliament had only convened in February 1920, under new party formations (Hubai 2001, 21-22).

${ }^{11}$ Such arguments were generally factitious, as outbursts of anti-Semitist violence occurred throughout the interwar era (Ladányi 2012, 84, 87, 100).

${ }^{12}$ Also, the Hungarian economy enjoyed growth during the mid-20s as a result of steady prices of agricultural produce. According to Ungváry, this enabled the government to ease down the authoritarian policies, of which anti-Semitism was a part (Ungváry 2013, 127).
} 
Hungarian political mentality; Hungarian matters had received positive attention in Europe and crisis measures could be mitigated, if even with rhetorical concessions. Hungary still nurtured hopes for revision of the Trianon treaty through international moderation and wanted to avoid negative attention from the League of Nations (Ladányi 2012, 80-82, 85).

Amidst domestic pressure and international expectations, after repeated calls for amendment from the Hungarian liberals and the liberal circles of the Unity party, as well as numerous postponements on handling the matter on behalf of the government (Ladányi 2012, 72-73), Bethlen and Kunó Klebelsberg'13 finally made a virtue out of necessity, introducing the amendment to Numerus Clausus law. Even the Jewish bourgeoisie had a role to play in the domestic consolidation and economic stabilization, and one reason for the amendment was to help them co-operate with their business partners in the Western Europe, who otherwise might have boycotted Hungary. That is, to help draw investments from the same international Jewish capitalists, whom the governments were rhetorically fighting (Kovács 2012, 32).

\section{The Amendment debate - the heyday of consolidation?}

The brief modification to Numerus Clausus, debated in the Lower House of the Hungarian Parliament14 between February $2^{\text {nd }}$ and 28th 1928, removed the explicit quotas of race and nationality from university enrolment and replaced them with an instruction to take into account the applicant's school performance as well as social background. It ordered to ensure that war orphans and children of veterans get study places in adequate numbers, and that children of different societal groups get places in relation to the proportion of the said group in the whole population (Law XIV/ 1928, §1). In principle the law abolished the ethnicity-based discrimination that had gathered negative attention internationally, but in practice replaced it with vague wording that still allowed universities to use 'national fidelity' as entrance requirement, i.e. to leave persons of suspicious background (ethnic or class-based) without place. The interest of the government was still to contain the number of Jewish students, but also to avoid international condemnation for racial segregation. This unspoken intention was widely known within the Hungarian political and academic elite (Kovács 2012, 52-53).

As mentioned above, the Hungarian demand for international credibility and support for its revision project was an inseparable element in the debates. The public arguments for modification stemmed from international sphere: Numerus Clausus had been used as a pretext for persecution of Hungarian minorities living in the neighbouring countries (Farkas 1928). This followed the established narrative about Hungary as the sole victim of the fervent, anti-Hungarian nationalism of its neighbours (see e.g Zeidler 2007, 86-87, 90-91). Thus, the defence of nation was rearticulated as integrating and culture-building policy, which left the concepts of discrimination and segregation only for the neighbouring countries. In Hungary everyone was now allowed (and expected) to participate in nationbuilding, regardless of class, nationality or religion (Farkas 1928; Klebelsberg 1928a).

\footnotetext{
${ }^{13}$ Klebelsberg, minister of education and church affairs since 1922, was a close ally of Bethlen, but also an active apologist of the Numerus Clausus in the international forums such as the League of Nations (Ladányi 2012, 75-78).

${ }^{14}$ Bicameral Parliament was established in 1927; the former National Assembly (Nemzetgyúlés) became the House of Representatives (Képviselöház) and a House of Magnates (Förendiház) was re-created according to the pre-war model (Püski 2006, 247-248).
} 
The discourse of objectivity was also connected to the redefinition of impartiality: the government wanted to distance itself from political extremes, of which the Left demanded complete abolishment of Numerus Clausus, the radical Right even stricter measures of race defence. In that rhetoric, only the government possessed the wisdom to conduct moderate reforms (Klebelsberg 1928b). Kunó Klebelsberg, as the responsible minister, assured the House that government shall maintain constitutionalism and, through the modification, end the unconstitutional discrimination towards Jews (Klebelsberg 1928a).

Moderate reformism and international climate were also present in the speeches of the liberal opposition. Pál Hegymegi-Kiss reminded that Hungary should lean neither towards Soviet bolshevism nor Italian Fascism, but to build equality by abolishing all restrictions. He also reminded of the international goodwill towards Hungary, especially in Great Britain (see e.g. Romsics 1999, 193), which should be fostered by preventing all accusations of discrimination; therefore the law of university enrolment should be based only on individual abilities (Hegymegi-Kiss 1928). The argument was followed by critical evaluation of the results of Numerus Clausus: as estimated by the liberal opposition in 1920, the law had affected mostly poorer Christian Hungarians, whereas Jewish students had moved to foreign universities (Hegymegi-Kiss 1928). ${ }^{15}$

Within eight years, the consolidation discourse had become powerful enough that Hegymegi-Kiss dared to lean on it in his speech, arguing for the total abolishment of the Numerus Clausus, and moreover, received not insults but applause (Hegymegi-Kiss 1928). This kind of equality-discourse was unheard of in the bitter antagonistic discourse of 1920; at that time Hegymegi-Kiss would not have been allowed to finish a similar speech at all (cf. Pető 1920; Sándor 1920; Bródy 1920). During the debates of 1928 interruptions were kept at minimum and also observed much more strictly by the Speaker than in 1920 (see e.g. Baracs 1928).

Another noteworthy change in the parliamentary climate and composition was that Social Democrats had gained representation since 1922 (Hubai 2001, 34). In her speech, Anna Kéthly, a Social Democrat and one of the two female MPs, approached the Numerus Clausus from class perspective, without racial or nationalist terminology. She stated that the law was merely a safeguard of the old elites, restricting societal mobility. She also paid attention to the vague wording, which in practice allowed for arbitrary discrimination. Another argument was temporal: as of 1928, those applying to universities had been under 10 years old during the revolutions; if the wording of national fidelity remained in the law, it was clearly aimed to judge children by the actions of their parents and thus maintains class distinctions, regardless of the kind words about consolidation (Kéthly 1928).

Those supporting the government's proposal denied that any means of social or ethnic discrimination remained. They argued that when racial and nationality quotas were abolished, no accusation of anti-Semitism, nor philo-Semitism was valid; thereafter the Numerus Clausus in its reformed form was an objective tool of consolidation, nothing else (see e.g. Szabó 1928; Jánossy 1928). Klebelsberg finalized the argument by stating that limitations of university enrolment as such were still needed due to the distress of Hungary, but no more through discrimination:

\footnotetext{
${ }^{15}$ Already by the mid-1920s it turned out that the gap in university enrolment resulting from rejection of Jews was not filled by Christian Hungarians and many university courses were below expected strength. This was one of the premises of amending the law (Kovács 2012, 34-35).
} 
(3) "At the moment they suffer because of being Jews. In the future they will only suffer because they are Hungarians, sons of this post-Trianon Hungary. They have to understand that we are obliged to share a smaller loaf of bread between us, and that no one may be given a bigger piece than to others."

(Most szenvednek azért, mert zsidók, akkor szenvedni fognak csak azért, mert magyar emberek, mert ennek a trianoni Magyarországnak fiai. Értsék meg, hogy kisebb kenyeret vagyunk kénytelenek egymás között megosztani és értsék meg, hogy nagyobb darabot ebból a kis kenyérból senkinek sem lehet adni. Klebelsberg 1928b)

The Race-defenders still raised their voices demanding the prolongation of the quotas. But even their rhetoric had incorporated appeasing tones. Predictably Gyula Gömbös opposed the modification, stating that Jews indeed were culturally and racially distinct from Hungarians, but then calmed down by asking whether Jews couldn't just be proud of their nationality. He also admitted that even though Numerus Clausus was a strict measure, it was a temporary one (Gömbös 1928). Gömbös again worded his endorsement of national values and racial defence, but treated them as subordinate to the 'strength and prosperity' of the Hungarian nation, which, he admitted, would prevail also under the amended conditions (Gömbös 1928). This conciliatory tone mirrored his requested mitigation of the antagonism between race defenders and conservatives: Gömbös had nominally returned to the Unity party and was obliged to quiet down his personal power ambitions. One can thus also interpret that at that moment the race-defenders were actually doing a favour to the government, presenting the expected extremist point of view, from which the government could then duly resign in the promotion of its newly-found policy of tolerance.

The mitigating discourse was to be prophetical: Gömbös's forthcoming victory over the conservative line of István Bethlen turned out to be a pyrrhic one. As he gained premiership in 1932, the radical aims of his policies were limited by the conservative parliamentary opposition (see e.g. Püski 2006, 269-270), and after his death in 1936 the radical Right had already been split between the older race-defenders and the more recent movements, direct imitations of National Socialism (Kontler 1999, 368-369; Hanebrink 2006, 138-139). The following debates on anti-Semitist legislation after 1938 were to be conducted under completely different circumstances and resulted in much more severe discrimination (Ungváry 2013, 184-186).

\section{Conclusions: the pitfalls of a 'gentlemanly' anti-Semitism}

A scholar in the interwar Hungarian history must be exactly aware of the relatively small but significant differences within the concept of political Right. The whole political structure was based on rather narrow elite that restricted wide public participation in politics. Many of its actions can be seen from today's perspective as far-right. However, this may also lead to one-sided interpretations (see Bodo 2010, 705; cf. Paxton \& Hessler 2012). A more analytical approach accepts the presence of manifold alignments and undercurrents, and analyses their relations and changes as a basis of political development. The road from postWar counterrevolutionary thought to the rise of extreme Right in the late 1930s was marked by numerous changes alternately in favour of several factions. One has therefore to be able to distinguish between Hungary's foreign political inclination towards Fascist states in the 1920s and 1930s and the rise of Hungarian domestic extreme Right (see e.g. Paksa 2013). Even after the national radical Gyula Gömbös, a personal admirer of Mussolini and Hitler, 
gained premiership in 1932, he campaigned against Hungarian National Socialist parties and, for example, imposed the ban of using swastika as party symbol. ${ }^{16}$

Despite the differentiation between the said groups, each government was in turn ready to use anti-Semitism as a tool of nation building, should the need arise. The mentality of Jews' otherness, denial of assimilation in the Hungarian society, was the principal argument behind these measures. Upon that basis, the legitimization for Numerus Clausus -type limitations were built within the quasi-rational arguments of proportional equality and conditional liberty. Once initiated, the anti-Semitist discrimination was soothed, at least rhetorically, but in practice never reversed. Even as the wording of the modification of 1928 did appear as non-racial, the proportion of Jews in Hungarian academia was not allowed to recover above the original quotas set in 1920 (Ungváry 2013, 22). Moreover, it has to be noted that Judaism was racialized exactly through the Numerus Clausus; its implementation in the Hungarian academia, in the very attempt to identify and reject Jewish applicants, moved the concept of Jew away from self-proclaimed definition through faith and towards externally defined definition through ethnicity (Kovács 2012, 30).

During the interwar era, the Hungarian nation-building debates included various forms of anti-Semitic discourses and arguments, which can be distinguished from each other. Firstly, the post-revolutionary discourse equated Jews with the utterly traumatizing revolutions and thus sought out to minimize their role in counterrevolutionary Hungarian society. Secondly, the conservative and consolidating discourse did not see any harm in Jewish individuals but wanted to end their 'over-representation' in more or less gentlemanly way and even sought approval from Jews themselves. As Prime Minister Bethlen put it:

(4) "I admit that there currently exists a Jewish question in the country, but its solution is that in the economic area we have to learn to live without them, as well as with them. It's also in their own interest, because at the moment when they no longer are indispensable, harmony shall return."

(Elismerem, hogy jelenleg van zsidókérdés az országban, de ennek megoldása az, hogy gazdasági téren azok lehessünk nélkülük is, amik velük együtt vagyunk. Ez őnekik is erdekük, mert abban a percben, amint nem lesznek nelkülözhetetlenek; abban a percben az összhang itt helyre fog allni. Bethlen 1921)

The diverse nature and diverse motives of Hungarian anti-Semitism were embodied by the change of the concept of örségváltás, 'change of the guard'. For the reactionary conservative elite it meant some vague, yet peaceful process, where the Hungarian Jewry would voluntarily cede its economic influence in favour of the new Christian middle class (Püski 2006, 59; Turbucz 2011, 168, 189; Ungváry 2013, 125). They nurtured this idea of gentlemanly anti-Semitism even in the late 1930s, when a totally new breed of extreme Right had taken over the anti-Semitist discourse; for them, örségváltás became to imply the Final Solution (Halmesvirta 2013).

\section{Afterw ord: Reappearances of anti-Semitist and anti-Liberal rhetoric}

Anti-Semitist rhetoric remains a troublesome part of exclusive nation-building in the Hungarian political language. Since 2010 the nationalist-populist governments under Viktor Orbán have presented apologetic explanations on the anti-Semitism of the interwar era and Hungarian participation in the Holocaust, as well as appealed to xenophobic values in their

${ }^{16}$ This in turn led to the choice of arrow-cross as the principal symbol of Hungarian extreme Right (Püski 2006, 91-92). 
strife against the domestic opposition and their 'freedom fight' against foreign intervention, most notably decrees of the European Union.

2014 was officially named the Holocaust memorial year, marking the 70th anniversary of the German occupation in March 1944, when, during the last stage of Second World War, Hungary sought separate peace with the Allies, but was in turn occupied by its former ally. A monument erected on the memorial year depicts the German Reichsadler attacking archangel Gabriel, the patron saint of Hungary - thus creating an explicit distinction between the foreign occupiers and the innocent victims (see Czenkli 2014). Historiography presented by the government marks the beginning of Holocaust in Hungary to that phase, effectively whitewashing the Hungarian anti-Semitist policies of the interwar era, the deportations of non-Hungarian Jews to German-controlled Poland and Ukraine, as well as assignment of Hungarian Jews to forced labour companies during the war (Holocaust Memorial Year 2014; cf. Ungváry 2013).

The anti-Semitist discourse in wider sense is also alive. Even if one ignores the explicit antiSemitic hate speak of the extreme Right, more or less veiled anti-Semitism can be found in the government communication as well. Whereas using arguments of 'Jewish overrepresentation' in contemporary Hungary would be absurd from the demographic viewpoint, ${ }^{17}$ attention has been concentrated on the even more conspiratorial arguments of Jewish 'invisible power' through the use of the already mentioned concepts of 'international capital' or 'international speculators' as the stereotype of forces hostile towards Hungary (see eg. Ripp 2010).

Especially the government's use of George Soros ${ }^{18}$ as the main organizer behind all criticism of the government, be it the European Union, domestic opposition or the Hungarian civil society, 19 is based on image of Soros as archetypical, unpatriotic and conspiratorial Jewish plutocrat. Until recently, the official communication has refrained from explicitly mentioning his Jewish background, but in May 2017 the Hungarian state TV channel M1 conceptualized Soros, in an out-of-context quote from the Iranian Ayatollah Ali Khamenei, as an 'evil Zionist' purportedly organizing revolutions and hostile takeovers around the world and now targeting Hungary (Mazsihisz 2017). Thus, the government openly and impudently exploits the anti-Semitist mentality still alive in Hungary.

In line with allegations of Jewish domination, liberalism is also applied as a negative catchword, a tool of foreign powers in their pursuit of weakening Hungary. In his infamous speech on July 2014, Orbán openly expressed his will to distance Hungary from 'foreign liberalism' that had not brought anything good for Hungary since the change of Regime in 1989 (Orbán 2014b). In his third premiership inauguration speech in 2014 he even reinstated the interwar-era argument of conditional liberalism: according to him, the principle of liberalism had been that everything is free as long as it doesn't harm others. But as long as a higher moral standard doesn't outline what actually doesn't harm others, such freedom cannot be maintained (Orbán 2014a).

\footnotetext{
${ }^{17}$ In the 1920s, Jews comprised around 6 per cent of the population, in present-day Hungary the proportion is around 0,1 per cent (KSH 2011).

${ }^{18}$ Hungarian-born investor and philanthropist George Soros is also the main benefactor of the Central European University in Budapest. In April 2017, Hungarian parliament passed a bill aimed to restrict the operation of the CEU (see BBC 2017).

${ }^{19}$ See e.g. the barrage of articles aimed at Soros in the pro-government newspaper M agyar Idók (Gajdics 2017; M agyar Idók 2017a; M agyar Idők 2017b) as well as the official site of the government communication for international audiences (Kovács 2017).
} 
In their 'illiberal' nation-building, the Orbán governments have since 2010 been concentrating power in in a way unseen since 1989. The words of Gábor Ugron, a liberal MP criticizing the counterrevolutionary mentality of 1920 could have been uttered today:

(5) "... the limits of power between legislative, executive and judicial authorities are being intermingled. Day by day I can see more collisions between these separate powers. Organs of civil society are being moved under the supervision of legal institutions ..."

(...a törvényhozói, végrehajtói és birói hatalomnak hatásköri összezavarása történik meg, nap-nap után ezeknek a különböző hatásköröknek állandó összeütközését látom; társadalmi szervek nyulnak be állandóan ilyen törvényes faktorok hatáskörébe... Ugron 1920)

The all too evident connections between past and present make the study of the interwar political language most compelling. But they also pose considerable problems, both practical and research-ethical. As a scholar, one must distance oneself from drawing direct parallels between the interwar and present Hungary. However, one must neither ignore the existence of such connections, but analyse them with orderliness and verifiable argument.

\section{Acknowledgements}

I would like to thank Marion Löffler for the organization of the conference Democratic and Undemocratic Language in which this special issue originated, Karin Bischoff and Cornelia Ilie for their editorial work and encouraging comments concerning the article, as well as the editors and reviewers of JLP.

\section{References}

BBC. 2017. "Hungary passes bill targeting Central European University.” BBC News, April 4, 2017. http:// www.bbc.com/ news/ world-europe-39493758/ .

Bodo, Béla. 2010. "Hungarian Aristocracy and the White Terror." Journal of Contemporary History 45 (4): 703-724.

Czenkli, Dorka. 2014. "Áll a szobor, csorog a tojás - Jelentés a Szabadság térről." Magyar Narancs Online, July 20, 2014. http:// magyarnarancs.hu/ belpol/ szabadsag-termegszallasi-emlekmu-felallitva-tuntetes-90999/ .

Gajdics, Ottó. 2017. “Botka bontást is vállal.” Magyar Idók, May 27, 2017. http:/ / magyaridok.hu/ ahelyzet/ botka-bontast-vallal-1752442/ .

Halmesvirta Anssi. 2013. "Unkarin äärioikeistoliikkeet 1930-luvulla." Historiallinen aikakauskirja 111 (3): 354-359.

Hanebrink, Paul A. 2006. In Defence of Christian Hungary. Religion, Nationalism and Antisemitism, 1890-1944. Ithaca: Cornell University Press.

Holocaust Memorial Year. 2014. "Holocaust in Hungary." http:/ / holocaustmemorialyear2014.gov.hu/ holocaust-in-hungary/ .

Hubai, László. 2001. Magyarország XX. századi választási atlasza, 1920-2000 (I). Budapest: Napvilág Kiadó.

Häkkinen, Teemu. 2014. "The Royal Prerogative Redefined: Parliamentary Debate on the Role of the British Parliament in Large-scale Military Deployments, 1982-2003." Jyväskylä Studies in Humanities vol. 224. PhD diss., University of Jyväskylä. 
Ihalainen, Pasi. 2016. "European Parliamentary Experiences from a Conceptual Historical Perspective." In Parliament and Parliamentarism: A Comparative History of a European Concept, edited by Pasi Ihalainen, Cornelia Ilie and Kari Palonen, 19-31. New York: Berghahn.

Ilie, Cornelia. 2016. "Parliamentary Discourse and Deliberative Rhetoric." In Parliament and Parliamentarism: A Comparative History of a European Concept, edited by Pasi Ihalainen, Cornelia Ilie and Kari Palonen, 133-145. New York: Berghahn.

Kaarkoski, Miina. 2016. “'Energiemix' versus 'Energiewende': Competing Conceptualisations of Nuclear Energy Policy in the German Parliamentary Debates of 19912001.” Jyväskylä Studies in Humanities vol. 290. PhD diss., University of Jyväskylä.

Karady, Victor, and Peter Tibor Nagy, eds. 2012. The Numerus Clausus in Hungary. Studies on the First Anti-Jewish Law and Academic Anti-Semitism in Modern Central Europe. Budapest: Central European University. http:/ / mek.oszk.hu/ 11100/ 11109/ 11109.pdf.

Kontler, László. 1999. Millennium in Central Europe. A History of Hungary. Budapest: Atlantisz Publishing House.

Kovács, Mária M. 2012. "The Hungarian Numerus Clausus: Ideology, Apology and History, 1919-1945." In The Numerus Clausus in Hungary. Studies on the First Anti-Jewish Law and Academic Anti-Semitism in Modern Central Europe, edited by Victor Karady and Peter Tibor

Nagy, 27-55. Budapest: Central European University. http:/ / mek.oszk.hu/ 11100/ 11109/ 11109.pdf.

Kovács, Zoltán. 2017. "Myths and Facts about Hungary and George Soros (Part 2)." About Hungary, May 30, 2017. http:// abouthungary.hu/blog/myths-and-facts-hungary-andgeorge-soros-part2/.

KSH. 2011. “2011 évi népszámlalás, Demográfiai adatok.” Központi sztatiztikai hivatál. http:/ / www.ksh.hu/nepszamlalas/demografiai_adatok_sb/ .

Ladányi, Andor. 2012. "On the 1928 Amendment to the Hungarian Numerus Clausus Act." In The Numerus Clausus in Hungary. Studies on the First Anti-Jewish Law and Academic AntiSemitism in Modern Central Europe, edited by Victor Karady and Peter Tibor Nagy, 69-111. Budapest: Central European University. http:/ / mek.oszk.hu/ 11100/ 11109/ 11109.pdf.

Magyar Idők. 2017a. "Deutsch Tamás: Soros indított hadjáratot a magyar kormány ellen, nem fordítva." Magyar Idôk, May 29, 2017. http:// magyaridok.hu/ belfold/ deutsch-tamassoros-inditott-hadjaratot-a-magyar-kormany-ellen-nem-forditva-1761673/ .

Magyar Idők. 2017b. "Fidesz: Újabb nyomásgyakorolás a mai tüntetés." Magyar Idók, May 29, 2017. http:// magyaridok.hu/ belfold/ fidesz-ujabb-nyomasgyakorlas-mai-tuntetes$1762852 /$.

Mazsihisz. 2017. “Magyarországon nem bűn sem zsidónak, sem cionistának lenni.” May 25, 2017. http:/ / www.mazsihisz.hu/ 2017/ 05/ 25/ magyarorszagon-nem-bun-sem-zsidonak,sem-cionistanak-lenni-10549.html/ .

Orbán, Viktor. 2014a. “Orbán Viktor beszéde a miniszterelnöki eskütételét követően.” May 10, 2014. http:// 2010-

2015.miniszterelnok.hu/beszed/ orban_viktor_beszede_a_miniszterelnoki_eskutetelet_kov etoen/ .

Orbán, Viktor. 2014b. “Orbán Viktor beszéde a XXV. Bálványosi Nyári Szabadegyetem és Diáktáborban." June 26, 2014. http:/ / www.kormany.hu/ hu/ a-miniszterelnok/ beszedekpublikaciok-interjuk/ a-munkaalapu-allam-korszaka-kovetkezik/ . 
Paksa, Rudolf. 2013. Magyar nemzetisocialisták. Budapest: Osiris Kiadó.

Paxton, Robert O., and Julie Hessler. 2012. Europe in the Twentieth Century. Fifth Edition. Boston: Wadsworth.

Püski, Levente. 2006. A Horthy-rendszer. Budapest: Pannonica Kiadó.

Ripp, Zoltán. 2010. “Egy szürke eminenciás színeváltozásai.” Mozgó Világ Online, January 2010. http:/ / epa.oszk.hu/ 01300/ 01326/ 00111/ MV_EPA01326_2010_01_10.htm.

Romsics, Ignác. 1999. Hungary in the Twentieth Century. Translated by Tim Wilkinson. Budapest: Corvina.

Romsics, Ignác. 2001. "Bevezetés. A történetírás objektivitásának mítoszáról és a múlt tmitizálásának elfogafhatatlanságáról." In Mítoszok, legendák, tévhitek a 20. századi magyar történelemról, edited by Ignác Romsics, 7-27. Budapest: Osiris Kiadó.

Sakmyster, Thomas L. 1994. Hungary's Admiral on Horseback. Miklós Horthy, 1920-1944. New York: Columbia University Press.

Skinner, Quentin. 1999. "Rhetoric and Conceptual Change." Finnish Yearbook of Political Thought Vol. 3: 60-73.

Turbucz, Dávid. 2011. Horthy Miklós. Budapest: Napvilág Kiadó.

Ungváry, Krisztián. 2013. A Horthy-rendszer mérlege. Diszkrimináció, szociálpolitika és antiszemitizmus Magyarországon. Budapest: Jelenkór Kiadó.

Zeidler, Miklós. 2007. Ideas on Territorial Revision in Hungary, 1920-1945. Translated by Thomas J. and Helen DeKornfeld. Boulder, CO: Social Science Monographs.

\section{Appendix. Full references to the original sources}

Archival sources:

Library of the Hungarian Parliament (Országgyúlési Könyvtár), web archive of Parliamentary documents (Országgyúlési dokumentumok), http:/ / mpgy.ogyk.hu/ .

Protocols of the National Assembly (Nemzetgyúlési napló, NN), V/ 1920. library.hungaricana.hu/ hu/ view/ OGYK KN-1920_05/.

Debate on the Bill concerning the rules of enrolment in the Universities, the Technical Universities, the Faculty of Economics at the University of Budapest and the Academies of Law (A tudományegyetemekre, múegyetemre, a budapesti egyetemi közgazdaságtudományi karra és a jogakadémiákra való beiratkozás szabályozásáról szóló törvényjavaslat).

Bernólak, Nándor. 1920. September 3, 1920, NN V/ 1920, 184189.

Bottlik, József (as the Speaker of the National Assembly). 1920. September 21, 1920, NN V/ 1920, 481.

Bródy, Ernö. 1920. September 21, 1920, NNV/ 1920, 476-478. 
Dinich, Vidor. 1920a. September 16, 1920, NNV/ 1920, 342.

Dinich, Vidor. 1920b. September 17, 1920, NN V/ 1920 357358.

Ereky, Károly. 1920. September 21, 1920, NNV/ 1920, 463

Haller, István. 1920a. September 2, 1920, NN V/ 1920, 150159.

Haller, István. 1920b. September 21, 1920, NN V/ 1920, 464471.

Herrmann, Miksa. 1920. September 16, 1920, NNV/ 1920, 353-356.

Giesswein, Sándor. 1920. September 18, 1920, NN V/ 1920, 387-388.

Gömbös, Gyula. 1920. September 17, 1920, NN V/ 1920, 371375.

Kovács, Émil. 1920. September 21, 1920, NNV/ 1920, 453.

Milotay, István. 1920. September 18, 1920, NNV/ 1920, 393396.

Pető, Sándor. 1920. September 3, 1920, NN V/ 1920, 190-195.

Prohászka, Ottokar. 1920. September 16, 1920, NN V/ 1920, 343-350.

Rupert, Rezső. 1920. September 18, 1920, NN V/ 1920, 412422.

Sándor, Pál. 1920. September 21, 1920, NNV/ 1920, 459-462.

Schandl, Károly. 1920. September 16, 1920, NN V/ 1920, 335341.

Szabó, Balázs. 1920. September 17, 1920, NNV/ 1920, 359364.

Szádeczky, Lajos. 1920. September 3, 1920, NNV/ 1920, 173175.

Szűcz, Dezső. 1920. September 17, 1920, NNV/ 1920, 378379.

Ugron, Gábor. 1920a. September 17, 1920, NNV/ 1920, 362370.

Ugron, Gábor. 1920b. September 18, 1920, NNV/ 1920, 382383. 
Usetty, Ferenc. 1920. September 2, 1920, NN V/ 1920, 148149.

Vasadi-Balogh, György. 1920. September 3, 1920, NNV/ 1920, 177-179.

Protocols of the National Assembly (Nemzetgyúlési napló, NN), IX/ 1920. library.hungaricana.hu/ hu/view/ OGYK_KN-1920_09/ .

Programme speech of the Prime Minister (A ministerelnök programmbeszéde).

Bethlen, István. 1921. April 19, 1921, NN IX/ 1920, 184-193.

Protocols of the House of Representatives (Képviselóházi napló, KN), VIII/ 1927. library.hungaricana.hu/ hu/ view/OGYK_KN-1927_08/ .

Protocols of the House of Representatives (Képviselóházi napló, KN), IX/ 1927. library.hungaricana.hu/ hu/view/OGYK_KN-1927_09/.

Debate on the Bill concerning the amendment of the Law XXV/ 1920 concerning the rules of enrolment in the Universities, the Technical Universities, the Faculty of Economics at the University of Budapest and the Academies of Law (A tudományegyetemekre, a múegyetemre, a budapesti egyetemi közgazdaságtudományi karra és a jogakadémiákra való beiratkozás szabályozásáról szóló 1920. évi XXV. tc. módosításáról szóló törvényjavaslat).

Baracs, Marcell. 1928. February 10, 1928 KN VIII/ 1927, 6-12.

Farkas, Elemér. 1928. February 9, 1928, KNVIII/ 1927, 438439.

Gömbös, Gyula. 1928. February 23, 1928, KN IX/ 1927, 185186.

Hegymegi-Kiss, Pál. 1920. February 2, 1928. KN VIII/ 1927, 440-444.

Jánossy, Gábor. 1928. February 14, 1928, KN IX/ 1927, 40-41.

Kéthly, Anna. 1928. February 10, 1928, KN IX/ 1927, 13-18.

Klebelsberg, Kunó. 1928a. February 10, 1928, KN IX/ 1927, 12-20.

Klebelsberg, Kunó. 1928b. February 23, 1928, KN IX/ 1927, 197, 201-202.

Szabó, Sándor. 1928. February 14, 1928, KN IX/ 1927, 27-30. 
Printed sources:

Law XXV/ 1920, Law concerning the rules of enrolment in the establishments of higher education (Törvény a felsőoktatási intézményekbe való beiratkozás szabályairól). In Magyar Történeti Szöveggyüjtemény 1914-1999 (I), edited by Ignác Romsics, 157-158. Budapest: Osiris Kiadó.

Law XIV/ 1928, Law concerning the amendment of the Numerus Clausus (Törvény a Numerus Clausus módodításáról). In Magyar Történeti Szöveggyüjtemény 1914-1999 (I), edited by Ignác Romsics, 234-235. Budapest: Osiris Kiadó.

\section{Author's address}

Ville Häkkinen

Department of History and Ethnology

University of Jyväskylä

40014 Jyväskylän yliopisto

Finland

ville.m.hakkinen@jyu.fi

\section{Biographical notes}

Ville Häkkinen, M.A. is a PhD candidate in the Department of History and Ethnology at the University of Jyväskylä, Finland. His research interests include political language, history politics and nation-building. 